- Collegium Medicum w Bydgoszczy

NATALIA WĄSIK

Okręgowa Izba Radców Prawnych w Olsztynie

TOMASZ KUCZUR

Uniwersytet Kazimierza Wielkiego w Bydgoszczy

\title{
Odpowiedzialność karna
}

\section{i odpowiedzialność za wykroczenia}

w związku z niedopełnieniem

\section{obowiązku odprowadzania składek}

\section{na ubezpieczenia społeczne}

Criminal liability and responsibility for misconduct in connection with failure to pay contributions for social insurance

Streszczenie. Celem niniejszej pracy jest omówienie charakteru i przyczyn uchybień związanych z kwalifikacją karną czynu polegającego na nieopłaceniu składek na ubezpieczenia społeczne, zagadnienie oceny zawinienia sprawcy, a także 
przedawnienia czynów jako konsekwencji ich niewłaściwej kwalifikacji karnej. Szeroka prezentacja ww. problemów docelowo powinna przyczynić się do wyeliminowania błędów, jakie mogą pojawić się w analogicznych sprawach, może także pomóc w ujednoliceniu orzecznictwa w tego typu sprawach. Na potrzeby niniejszego opracowania szczegółowo przeanalizowano przebieg trzech wybranych postępowań sądowych w sprawach karnych, prowadzonych w latach 20132015, dotyczących nieopłacenia w terminie składek na ubezpieczenia społeczne.

Słowa kluczowe: nieopłacenie w terminie składek na ubezpieczenia społeczne; uporczywość zachowania sprawcy; przywłaszczenie mienia publicznego; przedawnienie karalności.

Abstract. The purpose of this publication is to discuss the nature and causes of irregularities associated with criminal qualification of offense for not paying social security contributions, the issue of guilt evaluation, as well as limitation acts as a consequence of improper criminal qualifications. Presentation of the above. problems should eventually contribute to eliminating errors that may appear in similar cases, it may also help standardize case law. For the purposes of this study was analyzed in detail the course of three selected court proceedings in criminal cases, conducted in the years 2013-2015, concerning non-payment within social security contributions.

Keywords: failure to pay within the time limit of social security contributions; the persistence of behavior of the offender; misappropriation of public property; non-claim.

\section{Wprowadzenie}

Rzeczą charakterystyczną dla penalizacji nadużyć związanych z realizacją obowiązków wynikających z systemu ubezpieczeń społecznych jest uregulowanie tych zagadnień w różnych aktach prawnych - część jako przestępstwa, część natomiast jako wykroczenia. Co ciekawe, niemalże „blankietowa” budowa niektórych przepisów (por. art. $218 \S 1$ 1a k.k.) otwiera drogę do różnej interpretacji unormowań w zbliżonych stanach faktycznych, co niejednokrotnie budzi uzasadnione zastrzeżenia. Zagadnieniem szczególnie podatnym na pomyłki organów procesowych jest nieopłacanie w wymaganym terminie składek na ubezpieczenia społeczne. Praktyka 
wskazuje, że istnieją w tym obszarze liczne wątpliwości co do wykładni przepisów zarówno prawa karnego materialnego, jak i prawa wykroczeń.

Na potrzeby niniejszego opracowania szczegółowo przeanalizowano przebieg trzech wybranych postępowań sądowych w sprawach karnych, prowadzonych w latach 2013-2015, dotyczących nieopłacenia w terminie składek na ubezpieczenia społeczne. Przyjęto, że - z uwagi na charakter publikacji - adekwatną i efektywną metodą badawczą będą studia indywidualnych przypadków. W tekście pracy celowo zanonimizowano nazwy sądów rozstrzygających analizowane sprawy, a także daty zapadłych wyroków, pozostawiając jedynie sygnatury akt. We wszystkich badanych przypadkach, z uwagi na wystąpienie określonych błędów przy stosowaniu przepisów prawa karnego materialnego i procesowego, sądy odwoławcze uchylały w całości lub w części rozstrzygnięcia sądów I instancji.

Celem niniejszej pracy jest omówienie charakteru i przyczyn uchybień związanych z kwalifikacją karną czynu polegającego na nieopłaceniu składek na ubezpieczenia społeczne, zagadnienie oceny zawinienia sprawcy, a także przedawnienia czynów jako konsekwencji ich niewłaściwej kwalifikacji karnej. Zagadnienia te uczyniono przedmiotem pogłębionych rozważań. Szeroka prezentacja ww. problemów docelowo powinna przyczynić się do wyeliminowania błędów, jakie mogą pojawić się w analogicznych sprawach, może także pomóc w ujednoliceniu orzecznictwa w tego typu sprawach.

\section{Kwalifikacja karna niepłacenia składek na ubezpieczenia społeczne $w$ terminie}

Zgodnie z art. 98 ust. 1 pkt 1a ustawy z dnia 13 października 1998 r. o systemie ubezpieczeń społecznych ${ }^{1}$ czyn polegający na niepłaceniu składek na ubezpieczenia społeczne w wymaganym do tego terminie stanowi wykroczenie, za które ponosi odpowiedzialność płatnik składek albo osoba obowiązana do działania w imieniu płatnika nie dopełniający obowiązku

$1 \quad$ Tekst jedn. Dz.U. z 2015 r., poz. 121 ze zm. 
opłacania składek na ubezpieczenia społeczne w przewidzianym przepisami terminie. Sankcją karną jest w tym przypadku grzywna do 5000 zł.

Niezależnie od powyższego ustawodawca w art. $218 \S 1$ a k.k. ustanowił przestępstwo naruszania praw pracowniczych. W myśl przepisu kto, wykonując czynności w sprawach z zakresu prawa pracy i ubezpieczeń społecznych, złośliwie lub uporczywie narusza prawa pracownika wynikające ze stosunku pracy lub ubezpieczenia społecznego, podlega grzywnie, karze ograniczenia wolności albo pozbawienia wolności do lat 2 . W piśmiennictwie podkreśla się, że przedmiotem ochrony art. 218 k.k. są prawa pracowników z zakresu prawa pracy oraz ubezpieczeń społecznych. Jest to jednak zbiór na tyle pojemny, zawiera w sobie niemalże każdy obszar relacji pracownik-pracodawca (inny podmiot) ${ }^{2}$. Zachowanie sprawcy czynu zabronionego określonego w art. 218 § 1a k.k. zostało ujęte niezwykle szeroko, zaś ustalenie wyczerpującego katalogu praw pracownika wynikających ze stosunku pracy lub ubezpieczenia społecznego nie jest możliwe ${ }^{3}$.

Z konstrukcji cytowanych przepisów wynika, że nieodprowadzanie $\mathrm{w}$ terminie składek na ubezpieczenia społeczne co do zasady jest wykroczeniem. Jednakże gdy działanie to przybiera charakter „uporczywy” i „złośliwy”, może być zakwalifikowane jako przestępstwo z art. 218 § 1a k.k., co w praktyce niejednokrotnie ma miejsce.

Wątpliwości w powyższym zakresie sprowadzają się do pytania, czy długotrwałość nieopłacania składek na ubezpieczenia społeczne wyczerpuje znamię uporczywości zachowania sprawcy, o którym stanowi art. 218 § 1a k.k.

Wyniki analizowanych spraw karnych pozwalają na sformułowanie tezy, iż długotrwałość nieopłacania składek na ubezpieczenia społeczne eo ipso nie jest równoznaczna $\mathrm{z}$ uporczywością zachowania sprawcy, która stanowi znamię m.in. przestępstwa z art. 218 § 1a k.k. Przestępstwo $\mathrm{z}$ art. $218 \S 1 \mathrm{a}$ k.k. może być popełnione umyślnie z zamiarem bezpo-

2 G. Łabuda, Komentarz do art. 218 Kodeksu karnego [w:] J.W. Giezek (red.), Kodeks karny. Część szczególna. Komentarz, LEX 2014.

3 Z. Siwik, Komentarz do art. 218 Kodeksu karnego [w:] M. Filar (red.), Kodeks karny. Komentarz, LEX 2013. 
średnim, nacechowanym dodatkowo szczególny nastawieniem podmiotowym w postaci złośliwości lub uporczywości. Tylko z takim nastawieniem naruszenia praw pracowników wynikających z ubezpieczenia społecznego skutkuje przyjęciem bezprawności zachowania pracodawcy. W doktrynie dominuje natomiast pogląd, zgodnie z którym do momentu wypełnienia znamienia uporczywości sprawca popełnia wykroczenie z art. 98 ust. 1 pkt 1a u.s.u.s. Odnosząc powyższą tezę do wyników badań aktowych, przytoczyć należy przykład, gdzie w stanie faktycznym postępowania prowadzonego kolejno przez Sąd Rejonowy w R. (sygn. akt II K 418/12), a następnie przez Sąd Okręgowy w R. (sygn. akt II Ka 322/13), oskarżona kierowała do właściwych organów ZUS deklaracje z tytułu ubezpieczenia społecznego zatrudnionych u niej pracowników. Sąd Rejonowy w R. sprowadził zagadnienie znamienia w postaci uporczywości wyłącznie do kwestii długotrwałości - działania oskarżonej. Do takich wniosków prowadziło stwierdzenie w uzasadnieniu wyroku, iż działanie oskarżonej „nie miało charakteru incydentalnego, a rozciągnięte było w okresie 4 lat”. Tymczasem w ocenie Sąd Okręgowego w R. dowodziło to jednak tego, że intencją jej jako pracodawcy nie było uchylanie się od całkowitego uiszczenia składek zatrudnionych pracowników. W takiej bowiem sytuacji to nie pracownik, a płatnik składek jest dłużnikiem organu ubezpieczeniowego i z tego tytułu zatrudniony nie ponosi negatywnych konsekwencji. Jak zauważył Sąd Okręgowy w R. - ta świadomość o niepozbawianiu pracowników uprawnień sprawia, że pod względem podmiotowym nie wypełnia ono niezbędnych znamion występku z art. 218 § 1a k.k., którego sprawca musi działać ze świadomością wyrządzenia szkody prawom pracowników. Istniejącego wobec ZUS długu nie można bowiem w sposób prosty przekładać na występek przeciwko interesom zatrudnionych pracowników.

W świetle powyższego zasadnym wydaje się stwierdzenie, że o uporczywości na gruncie art. 218 § 1a k.k. nie świadczy tylko czasookres czy wielokrotność zachowań, ale przede wszystkim element woli ukierunkowanej na działanie w zamiarze naruszenia praw pracowników. Ocena uporczywości i długotrwałości ma charakter zindywidualizowany i musi być dokonywana odmiennie w zależności od konkretnego stanu 
faktycznego. Nieodprowadzanie składek na ubezpieczenia społeczne w terminie, nawet jeśli będzie ono działaniem rozłożonym na kilka lat, jeśli nie towarzyszy mu złośliwość działania sprawcy, intencjonalne wprowadzanie w błąd pracowników co realizacji obowiązku, względnie tzw. uciekanie z majątkiem (np. cesje wierzytelności, podejmowane ad hoc inwestycje kosztem realizacji obowiązków publicznoprawnych, spłata zadłużenia, przed którym obowiązek publicznoprawny ma pierwszeństwo zaspokojenia etc.), nie będzie naruszać prawa osób wykonujących pracę zarobkową do świadczeń z ubezpieczenia społecznego, o którym mowa w art. 218 k.k., ale stanowić będzie naruszenie obowiązków płatnika wobec ZUS (art. 98 ust. 1 u.s.u.s.). Czyny te godzą w różne dobra prawne, co zawsze wyłącza tożsamość czynu ${ }^{4}$.

Innym ważnym problemem związanym z kwestią znamienia uporczywości jest ocena stopnia zawinienia sprawcy nieodprowadzania $\mathrm{w}$ terminie składek na ubezpieczenia społeczne. Uporczywość działania wiąże się przeważnie wyłącznie z zawinionym zachowaniem sprawcy. W odniesieniu do omawianej kategorii czynów przyjmuje się, że jeżeli płatnik środków finansowych nie posiada, czego najlepszym przykładem jest niedokonanie wypłaty wynagrodzeń pracownikom przy pobieranym podatku dochodowym od osób fizycznych, a nie można środków tych również pozyskać na innej drodze (np. kredyt lub pożyczka), odpada wina w działaniu sprawcy, nie można wówczas od płatnika w takiej sytuacji wymagać zachowania zgodnego z prawem, którego nie jest on w stanie wykonać. $\mathrm{Z}$ tego względu konieczna jest analiza sytuacji finansowej oskarżonego (pracodawcy) w zestawieniu z terminami wypłaty wynagrodzeń pracownikom i nieodprowadzeniem składek do ZUS może mieć istotne znaczenie nie tylko dla oceny bezprawności i karygodności jego zachowania, ale przede wszystkim dla oceny stopnia zawinienia sprawcy.

4 K. Woźniewski, Glosa do wyroku TK z 18 listopada 2010, P 29/09, „Gdańskie Studia Prawnicze - Przegląd Orzecznictwa” 2011, z. 2, s. 151 i n. 


\section{Prawa pracownika a prawa z ubezpieczenia społecznego}

Powielanym błędem orzeczniczym w sprawach dotyczących nieodprowadzania składek na ubezpieczenia społeczne jest utożsamianie tego czynu z naruszeniem praw pracowniczych. Tak np. w sprawie rozpatrywanej przez Sąd Okręgowy w B. (sygn. akt IV Ka 585/14) na skutek apelacji od wyroku Sądu Rejonowego w B. (sygn. akt III K30/11) zauważono, że z treści art. 218 § 1a k.k. wynika jednoznacznie, że naruszenie może dotyczyć praw pracownika mających jedno z dwóch źródeł - stosunek pracy lub ubezpieczenie społeczne. Odmienne źródło tych praw wpływa w tej sytuacji na zróżnicowany przedmiot ochrony, albowiem regulacja $\mathrm{z}$ art. $218 \S 1$ a k.k. może chronić odpowiednio albo prawa pracownika wynikające ze stosunku pracy, np. prawo do wynagrodzenia, albo prawa wynikające $\mathrm{z}$ ubezpieczenia społecznego, np. związane z wywiązywaniem się z obowiązków płatnika tego podatku, a w praktyce oznacza to prawo do otrzymania świadczenia z ubezpieczeń społecznych na wypadek zaistnienia ku temu przesłanek. Odmienny jest również sposób wywiązywania się z tego obowiązku, bo środki z tytułu ubezpieczeń społecznych przekazywane są na rachunek Funduszu Ubezpieczeń Społecznych oraz Funduszu Ubezpieczeń Zdrowotnych, natomiast wynagrodzenie wypłacane jest, co do zasady, bezpośrednio na rachunek albo do rąk pracownika. Uprawnienia pracownicze, w tym uprawnienie do wynagrodzenia, mają swe źródło w kodeksie pracy, natomiast uprawnienia z tytułu ubezpieczenia społecznego mają swoje źródło w prawie publicznym. Jednocześnie pokrzywdzonym przestępstwem z art. 218 § 1 a k.k., które polega na niewypłacaniu pracownikom wynagrodzenia w terminie, są sami pracownicy, natomiast nieodprowadzanie składek na FUS i FUZ dokonywane jest na szkodę również i przedmiotowych funduszy, inny więc jest zakres podmiotów pokrzywdzonych tymi zachowaniami ${ }^{5}$.

Jak słusznie zauważył Sąd Okręgowy w B. w omawianej sprawie, dwa zachowania: polegające na nieodprowadzaniu jako płatnik składek oraz na niewypłacaniu wynagrodzenia pracownikom, mają zasadniczo

5 Vide wyrok Sądu Najwyższego z dnia 1 marca 2013 r., V KK 394/12, LEX nr 1294462. 
odmienny charakter, nawet jeżeli - przy spełnieniu pewnych warunków zarówno jedno, jak i drugie zachowanie teoretycznie może wyczerpywać znamiona przestępstwa z art. $218 \S 1$ a k.k. Fakt, iż uprawnienia pracownicze oraz uprawnienia z tytułu ubezpieczenia społecznego wywodzą się z różnych źródeł oraz realizowane są w odmienny sposób, wiąże się bezpośrednio z odmiennym sposobem dokonania przestępstw i wykazywania naruszania tych praw, co z kolei skutkować musi innym ukierunkowaniem postępowania dowodowego. Cechą wspólną obu tych zachowań jest jedynie skutek w postaci naruszania ogólnie rozumianych praw pracowniczych przez podmiot, na którym spoczywają określone obowiązki związane z zatrudnianiem pracowników. Oczywiście działania sprawcy mogą skutkować naruszeniem uprawnień w obu tych sferach, jednakże taki zarzut musi być wyraźnie sformułowany przez prokuratora w akcie oskarżenia.

\section{Nieopłacenie składki na ubezpieczenia społeczne a przywłaszczenie mienia publicznego}

W praktyce zdarza się, że sprawcom czynów związanych z niedopełnieniem odprowadza składek na ubezpieczenia społeczne w terminie stawiane są zarzuty popełnienia takich przestępstw jak np. przywłaszczenie mienia (art. 284 k.k.) lub oszustwo (art. 286 k.k.).

Zgodnie z art. 284 § 1 k.k. kto przywłaszcza sobie cudzą rzecz ruchomą lub prawo majątkowe, podlega karze pozbawienia wolności do lat 3. W § 2 przepisu przewidziano natomiast, że kto przywłaszcza sobie powierzoną mu rzecz ruchomą, podlega karze pozbawienia wolności od 3 miesięcy do lat 5 .

Przykładu kwalifikacji karnej nieopłacenia składek na ubezpieczenia społeczne jako przywłaszczenie dostarcza omawiana wcześniej sprawa rozpatrywana kolejno przez Sąd Rejonowy w R. (II K 418/12), a następnie przez Sąd Okręgowy w R. (II Ka 322/13). Oskarżonej postawiono bowiem m.in. zarzut popełnienia czynu zabronionego określonego w art. $284 \S 2$ k.k. w zw. z art. 12 k.k., polegającego na tym, że działając w krótkich odstępach czasu w wykonaniu z góry powziętego zamiaru, prowadząc własną działalność gospodarczą i wykonując obowiązki z za- 
kresu prawa pracy i ubezpieczeń społecznych, przywłaszczyła sobie mienie powierzone w kwocie łącznej 32 870,26 zł w ten sposób, że potrąciła od wynagrodzeń brutto zatrudnionych pracowników składki w części finansowej przez ubezpieczonego na Fundusz Ubezpieczeń Społecznych, z których część składek winna być przekazana do Otwartych Funduszy Emerytalnych oraz Fundusz Ubezpieczenia Zdrowotnego, po czym pomimo obowiązku wynikającego z ustawy o systemie ubezpieczeń społecznych nie przekazała ich do właściwego Zakładu Ubezpieczeń Społecznych. Sąd I instancji podzielił argumenty prokuratora i skazał oskarżoną na podstawie ww. przepisów, wyrok ten jednak został uchylony przez Sąd Okręgowy w R.

W uzasadnieniu powyższego wyroku dokonano interesującego zestawienia unormowań w zakresie zobowiązań podatkowych ze zobowiązaniami dotyczącymi ubezpieczeń społecznych. Wyraźnie podkreślano, że kwalifikacja prawna nieopłacenia składek na ubezpieczenie społeczne wprawdzie nie jest całkowicie jasna, jednak doktryna i orzecznictwo dopuszczają, że nieopłacenie składek na ubezpieczenie społeczne może w niektórych wypadkach wiązać się również z odpowiedzialnością karną i uznaniem takiego czynu za przywłaszczenie powierzonego mienia lub za kradzież ${ }^{6}$. Sąd Okręgowy w R. wyszedł z założenia, że nieopłacenie przez płatnika składek we wskazanym terminie należy traktować per analogiam do tego typu zaniechań w zakresie nieodprowadzenia przez podatnika wymaganych kwot podatku, tj. postrzegać jako ich przywłaszczenie. Płatnik odpowiada - w zależności od wielkości przywłaszczonych kwot - za przestępstwo lub wykroczenie pospolite. Również na gruncie orzecznictwa dotyczącego niewpłacania na rachunek organu podatkowego należnego podatku przyjmuje się, że podatek jest pobrany wówczas, gdy dokonano jego potrącenia, tj. gdy wypłacono podatnikowi kwotę pieniężną po

$6 \quad$ Zob. K. Makowski, Niektóre aspekty odpowiedzialności płatnika składek z tytułu popetnienia przestępstwa lub wykroczenia, „Przegląd Ubezpieczeń Społecznych” 2000, nr 5, s. 7 i n.; J. Lachowski, Odpowiedzialność karna płatnika składek wybrane zagadnienia, „Praca i Zabezpieczenie Społeczne” 2004, nr 12, s. 24 i n. 
odliczeniu podatku podlegającego pobraniu ${ }^{7}$, zaś niewpłacenie na rachunek organu podatkowego obliczonego i pobranego podatku nie musi polegać na fizycznym przejęciu przez płatnika kwoty stanowiącej jego równowartość ${ }^{\text {. W }}$ praktyce, gdy płatnik (sprawca) nie posiada środków finansowych na uiszczenie podatku podatnika, najczęściej przyjmuje się fikcję pobrania podatku „na papierze”, gdy tymczasem w rzeczywistości płatnik nie dysponuje pieniędzmi na wpłatę podatku. Sąd Najwyższy jednak w wielu orzeczeniach akcentował, że kondycja finansowa płatnika nie ma znaczenia dla jego odpowiedzialności karnoskarbowej. Przyjmuje się bowiem, że środki pieniężne nie należą do płatnika, należą do podatnika (do czasu pobrania) i do Skarbu Państwa (od czasu wpłacenia), powinnością zaś płatnika jest jedynie obliczyć, pobrać podatek i wpłacić go na rachunek organu. Jeżeli zaś płatnik środki finansowe posiada, a przeznacza je jednak na inny uzasadniony ekonomicznie cel, zwłaszcza na podtrzymywanie działalności gospodarczej, w grę wchodzi jedynie umniejszenie winy, nigdy zaś jej wyłączenie. Przedstawione wyżej uwagi Sąd Okręgowy w R. odniósł do prawnokarnej sytuacji pracodawcy (płatnika) niewpłacającego na rzecz ZUS naliczonych i potrąconych z wynagrodzenia pracowników składek. Jeśli jednak płatnik (pracodawca) nie przekazuje do ZUS tej części składki, którą sam jest zobowiązany sfinansować, to trudno postawić mu jakikolwiek zarzut popełnienia innego czynu zabronionego niż wykroczenie, niezależnie od tego, na co przeznaczył w ten sposób zaoszczędzone środki. Jednocześnie płatnik, który najczęściej jest pracodawcą, nie może powoływać się na złą kondycję finansową „przedsiębiorstwa”, które prowadzi, dla uzasadnienia zaniechania opłacania składek ${ }^{9}$.

Warunkiem przypisania sprawcy popełnienia przestępstwa z art. 284 § 2 k.k. konieczne jest zatem ustalenie spełnienia znamion strony podmiotowej czynu, polegającej na tym, iż sprawca już w momencie naliczania

\footnotetext{
Zob. wyrok SN z dnia 19 sierpnia 1999 r., III KKN 434/97, „Prokuratura i Prawo 2000, z. 1, poz. 16; wyrok SN z dnia 16 maja 2002 r., IV KKN 427/98, „Prokuratura i Prawo" 2003, z. 2, poz. 12.

Wyrok SN z dnia 2 sierpnia 2002 r., IV KKN 426/98, LEX 55193.

Zob. również J. Lachowski, Odpowiedzialność karna płatnika składek..., s. 24 i n.
} 
pracownikowi wynagrodzenia miał zamiar dokonania tylko pozornego potrącenia należności, których następnie nie zamierzał odprowadzić do ZUS, tylko przywłaszczyć sobie tę kwotę. Przywłaszczenie jest bowiem przestępstwem kierunkowym, bo warunkiem odpowiedzialności jest działanie czy zaniechanie sprawcy w celu osiągnięcia korzyści majątkowej. Zamiar bezpośredni o szczególnym zabarwieniu związanym z celem działania sprawcy oznacza, że elementy przedmiotowe przywłaszczenia muszą mieścić się w świadomości sprawcy i muszą być objęte jego wolą. Sprawca nie tylko musi chcieć uzyskać korzyść majątkową, lecz musi także chcieć użyć w tym celu określonego sposobu działania czy zaniechania. Tym samym nawet świadomość kryzysowej sytuacji prowadzonej działalności gospodarczej może świadczyć o lekkomyślności, nie zaś o bezpośrednim zamiarze dokonania przywłaszczenia. Zamiar przywłaszczenia (animus rem sibi habendi) różni się od zamiaru przyjmującego postać działania w celu osiągnięcia korzyści majątkowej. Charakteryzujący stronę podmiotową cel przywłaszczenia jest pojęciem zakresowo węższym niż cel osiągnięcia korzyści majątkowej, zaś korzyść majątkowa stanowiąca cel działania sprawcy z zamiarem uzyskania korzyści (animus lucri faciendi) jest pojęciem szerszym niż przywłaszczenie mienia stanowiące znamię strony podmiotowej innych przestępstw przeciwko mieniu. Sprawca, działając w celu osiągnięcia korzyści majątkowej, nie musi dążyć do przywłaszczenia mienia stanowiącego przedmiot jego zachowania ${ }^{10}$.

W omawianej sprawie Sąd I instancji w uzasadnieniu zaskarżonego wyroku wskazał, iż niewpłacone składki oskarżona włączała do swojego majątku i postępowała jak z własnym mieniem, rozdysponowując na własne cele, przy czym nie wyjaśnił, jakie to były cele i czy możliwe w ogóle było przywłaszczenie przyjętej w zarzucie aktu oskarżenia łącznej kwoty 32.870,26 zł. Tymczasem - jak słusznie podkreślał Sąd Okręgowy w R. kondycja finansowa firmy oskarżonej była w przypadku zarzucanych jej czynów szczególnie istotna, tym bardziej że w sprawie chodziło o dość długi okres. Nie zbadano, czy w tym czasie oskarżona miała zaległości

10 Por. postanowienie Sądu Apelacyjnego w Krakowie z dnia 15 grudnia 2011 r., II AKz 476/11, „Krakowskie Zeszyty Sądowe” 2011, z. 12, poz. 32. 
finansowej wobec urzędu skarbowego i innych instytucji, zaś te okoliczności świadczyć bowiem mogą o możliwościach płatniczych oskarżonej, którą w czasie popełnienia zarzucanego jej czynu posiadała, jak również czy wypłacała pracownikom wynagrodzenia, regularnie w pełnych wysokościach, czy miała z tym problemy, czy korzystała z kredytów, jeżeli tak - to na co przeznaczała z nich środki, a następnie, czy terminowo spłacała. Okoliczności te można traktować uniwersalnie z racji na ogół podobnych zachowań sprawców nieodprowadzania w terminie składek na ubezpieczenia społeczne. Powinny one również stanowić istotną wskazówkę dla organów ścigania, które gromadząc materiał dowodowy, zobowiązane są zwrócić na nie szczególną uwagę i dopiero po przeanalizowaniu powyższych kwestii powinny rozważać możliwość postawienia sprawcy zarzutu popełnienia przestępstwa przywłaszczenia mienia.

\section{Błędna kwalifikacja karna czynu a przedawnienie jego karalności}

Jednym z najpoważniejszych skutków kwalifikacji karnej nieodprowadzania składek na ubezpieczenia społeczne może być przedawnienie karalności czynu. Z taką sytuacją mamy do czynienia wówczas, gdy zachowanie sprawcy zostanie potraktowane przez organy procesowe jako przestępstwo, podczas gdy znamiona tegoż nie występują lub nie zostaną dostatecznie wykazane. Wtedy okazuje się, że sprawca w ogóle nie poniesie odpowiedzialności w sferze prawa karnego czy prawa wykroczeń. Dobitnym przykładem takiego stanu rzeczy jest postępowanie prowadzone przed Sądem Okręgowym w B. (sygn. akt IV Ka 585/14) na skutek apelacji oskarżonego od wyroku Sądu Rejonowego w B. (sygn. akt III K30/11). W sprawie tej oskarżonemu zarzucono popełnienie przestępstwa z art. 218 §1a k.k., tymczasem opisane skargą publiczną zachowanie nie stanowiło przestępstwa, ale wykroczenie art. 98 ust. 1 u.s.u.s., za popełnienie którego ukaranie nie było już możliwe z uwagi na przedawnienie karalności.

Sąd I instancji, rozpatrując omawianą sprawę, przyjął, że gdyby nie nastąpienie przedawnienia karalności czynu, to zarzuty aktu oskarżenia, nieobejmujące naruszenia praw pracowniczych wynikających ze stosunku 
pracy, pozwalałyby zarówno na ukaranie za wykroczenie (zgodnie z opisem czynów zarzuconych), jak i na skazanie za przestępstwo (zgodnie z opisem czynów ostatecznie przypisanych). Orzekanie w tej materii oznaczało niedochowanie granic określonych skargą. Ostatecznie Sąd Rejonowy w B. uznał, że zarzucone oskarżonemu nieodprowadzenie składek na FUS i FUZ nie wyczerpywało znamion przestępstwa uporczywego naruszania praw pracowników wynikających z ubezpieczenia społecznego, czyli zarzuconego przestępstwa z art. 218 §1a k.k. Sąd ten nie analizował jednak ustalonego ostatecznie stanu faktycznego pod kątem odpowiedzialności na podstawie art. 98 ust. 1 pkt 1a u.s.u.s. Zauważyć należy, że przedawnienie orzekania nie jest bowiem generalną przeszkodą do uniewinnienia podsądnego ${ }^{11}$. Rozstrzygnięcie Sądu Rejonowego w B. doprowadziło jednak do szczególnej sytuacji, gdy prokurator zarzucił oskarżonemu popełnienie m.in. przestępstw, których czynność wykonawcza polegała na nieodprowadzaniu składek z tytułu ubezpieczenia społecznego. Sąd I instancji uznał, że oskarżeni nie mogą ponosić za to odpowiedzialności z uwagi na brak realizacji znamion przestępstwa. Mimo to skazał oskarżonych na tej samej podstawie prawnej (art. 218 § 1a k.k.), przyjmując, że czynność wykonawcza przestępstwa polegała na innym zachowaniu niż zarzucone, tj. na nieterminowym wypłacaniu pracownikom wynagrodzenia. O niedopuszczalności takiego rozstrzygnięcia orzekł Sąd Okręgowy w B. Nie do zaakceptowania była bowiem sytuacja, gdy opis czynu zarzuconego w akcie oskarżenia wskazuje na popełnienie czynu bezprawnego, mogącym być kwalifikowanym jedynie jako wykroczenie, na skutek zmiany tego opisu poprzez dodanie nowego i niezarzuconego zachowania skutkowałaby odpowiedzialnością za przestępstwo z art. 218 \& 1a k.k.

Kwestię przedawnienia karalności czynu rozpatrywał również Sąd Okręgowy w P., w sprawie sygn. akt IV Ka 703/14, rozpatrywanej na skutek apelacji od wyroku Sądu Rejonowego w R. (sygn. akt II K 717/13). Istotnym zagadnieniem w tym przypadku było określenie początku biegu

11 Por. postanowienie SN z dnia 7 czerwca 2006 r., II KK 34/06, LEX nr 192978; postanowienie SN z dnia 3 kwietnia 2002 r., V KKN 484/00, LEX nr 53336; postanowienie SN z dnia 27 stycznia 2011 r., I KZP 27/10, LEX nr 686691. 
terminu przedawnienia karalności wykroczenia. Sąd ten przyjął, że w związku z zatrudnieniem pracownika $X$ na podstawie umowy zlecenia na oskarżonym Y ciążył obowiązek dopełnienia obowiązku opłacania składek na ubezpieczenia społeczne w przewidzianym przepisami terminie, niemniej jednak zaniechanie w tym względzie nie mogło być traktowane w kategoriach żadnego z przepisów części szczególnej kodeksu karnego, w tym również w kwalifikacji prawnej art. 218 §1a k.k. oraz art. 219 k.k. Sąd Okręgowy w P. słusznie przyjął, że ochroną art. 218 §1a k.k. nie są bowiem objęte wynikające z przepisów o ubezpieczeniu społecznym prawa tych osób, które świadczą pracę w ramach innego stosunku, aniżeli opisany w art. $22 \S 1$ k.p. Natomiast uchylanie się od opisanego wyżej obowiązku składkowego nie jest objęte zakresem znamion występku z art. 219 k.k. (mowa w tym przepisie wyłącznie o bezprawności zachowania polegającego na naruszaniu przepisów prawa o ubezpieczeniach społecznych poprzez zaniechanie zgłaszania, nawet za zgodą zainteresowanego, wymaganych danych albo poprzez zgłaszanie nieprawdziwych danych mających wpływ na prawo do świadczeń albo ich wysokość). $\mathrm{W}$ tej sytuacji jedyną wchodzącą $\mathrm{w}$ grę konsekwencją niedopełnienia obowiązku opłacania składek na ubezpieczenie społeczne w odniesieniu do osób świadczących pracę na podstawie innej, aniżeli stosunek prawny o cechach opisanych w art. 22 § 1 k.p., jest odpowiedzialność za wykroczenie z art. 98 ust. 1a u.s.u.s., który stanowi, iż podlega karze grzywny, kto jako płatnik składek albo osoba obowiązana do działania w imieniu płatnika nie dopełnia obowiązku opłacania składek na ubezpieczenia społeczne w przewidzianym przepisami terminie. Tyle tylko, że stosownie do art. 45 §1 k.w. karalność wykroczenia ustaje, jeżeli od czasu jego popełnienia upłynął rok. Jeżeli w tym okresie wszczęto postępowanie, karalność wykroczenia ustaje z upływem 2 lat od popełnienia czynu. W kontekście powyższego wskazać należy, że w sytuacji, gdy sąd dochodzi do przekonania, iż zebrany w sprawie materiał dowodowy nie pozwala przypisać oskarżonemu przestępstwa, a w grę wchodzi jedynie odpowiedzialność za wykroczenie, za datę wszczęcia postępowania w rozumieniu art. 45 §1 k.w. należy uznać dzień, w którym przesłuchano go w charakterze podejrzanego na okoliczność postawionego zarzutu. Wydaje się, że ma to 
swoje uzasadnienie, albowiem istotnym $\mathrm{w}$ tej sytuacji jest nie szeroko pojęty formalizm procesowy, ale faktyczne powzięcie przez sprawcę wiedzy, że jego czyn był sprzeczny z obowiązującym porządkiem prawnym, co uzasadnia zastosowanie przyjętej w nim sankcji.

\section{Podsumowanie}

Nieopłacenie w terminie składek na ubezpieczenia społeczne niesie ze sobą wiele wątpliwości co do kwalifikacji karnej tego czynu. Należy on bowiem do tej grupy bezprawnych zachowań, które w pewnych sytuacjach wypełniają równocześnie znamiona różnych przestępstw i wykroczeń.

Zasadniczo samo nieopłacenie składek na ubezpieczenia społeczne w terminie jest wykroczeniem kwalifikowanym z art. 98 ust.1 pkt 1a u.s.u.s. Do przypisania sprawcy odpowiedzialności za jego popełnienie wymagane jest jednak brak jakichkolwiek wątpliwości co do istnienia zobowiązania płatnika i jego zakresu, np. brak sporu co do strony przedmiotowej i podmiotowej zobowiązania, czyli podstawy wymiaru składek i podmiotu zobowiązanego do ich naliczenia i odprowadzenia. Nie może też budzić wątpliwości okoliczność rzeczywistego odprowadzenia składek na ubezpieczenia społeczne.

Jednakże w przypadku, gdy sprawca nie dopełnia omawianego obowiązku w sposób uporczywy, co należy wiązać z działaniem umyślnym, złośliwym, np. wykazywaniem szczególnie lekceważącego stosunku do zobowiązań publicznoprawnych i ignorowaniem wszelkich wezwań organu, czy też ukrywania majątku, z którego można egzekwować składki, wówczas sprawcy można przypisać odpowiedzialność karną za popełnienie przestępstwa z art. 218 § 1a k.k. Uporczywości w zachowaniu sprawcy nie można jednak łączyć z samą tylko długotrwałością stanu zaległości i powtarzalnością zaniechań lub opóźnień w opłacaniu składek. Decydujące są tu wola i motywy zachowań płatnika.

Na gruncie art. 218 § 1a k.k. należy też wyraźnie rozdzielić nieodprowadzenie składek na ubezpieczenia społeczne od niezapłacenia pracownikowi wynagrodzenia za pracę. Obowiązki te mają bowiem inne źródła i wynikają z odmiennych stosunków prawnych. Zachowania te jako 
czynności sprawcze art. 218 § 1a k.k. nie mogą być stosowane alternatywnie przy konstruowaniu zarzutów lub w opisie czynu sprawcy w orzeczeniu sądowym. Jeżeli natomiast to samo zachowanie wpływa na oba zobowiązania: składkowe i pracownicze, musi to być jasno określone.

W wyjątkowych przypadkach odpowiedzialność karna sprawcy może też sprowadzać się do zarzutu popełnienia przestępstwa z art. 284 § 2 k.k. W takim wypadku wymagane jest ustalenie, że sprawca od początku istnienia obowiązku pozorował swoje działania, np. odprowadzał niepełną kwotę należności, pozostałą zaś faktycznie przywłaszczał i wydatkował środki na inne cele. Istotne jest ustalenie, czy są to cele prywatne, czy też opłacenie innych zobowiązań publicznoprawnych (np. podatkowych) kosztem zobowiązania składkowego. W tym drugim przypadku trudno mówić o przywłaszczeniu.

Jedną z najpoważniejszych konsekwencji nieprawidłowej kwalifikacji karnej niedopełnienia obowiązku opłacenia składek na ubezpieczenia społeczne w terminie jest ryzyko przedawnienia karalności czynu. Następuje to najczęściej w sytuacji postawienia zarzutu popełnienia przez sprawcę przestępstwa z art. 218 § 1a k.k. (przy błędnym założeniu uporczywości działania przestępnego), podczas gdy rzeczywiście czyn wyczerpuje znamiona wykroczenia z art. 98 ust. 1 pkt 1a u.s.u.s. Według przyjętego w orzecznictwie poglądu terminem początkowym biegu terminu przedawnienia, gdy nie wszczęto formalnie postępowania, będzie data przesłuchania sprawcy w charakterze podejrzanego. Pogląd ten należy w pełni zaaprobować, albowiem z tą chwilą podejrzany zapoznaje się z zarzutem stawianym mu przez organa ścigania, ma możliwość przeanalizowania prawidłowości ustalonego stanu faktycznego i podjęcia obrony w procesie. Nota bene te same elementy zawierałby wniosek o ukaranie za wykroczenie z art. 98 ust. 1 pkt 1a u.s.u.s. Przyjęcie konstrukcji odmiennej prowadziłoby z kolei do absurdalnej sytuacji, w której wykroczenie, w przypadku w którym proces karny o przestępstwo z art. 218 § 1a k.k. zakończyłby się prawomocnie np. po upływie dwóch lat, a organa ścigania dopiero z uzasadnienia wyroku dowiedziałby się o błędnej kwalifikacji czynu i naprawiły ten błąd post factum, karalność wykroczenia nastę- 
powałaby faktycznie po 4 latach od jego popełnienia, co jest niedopuszczalne w świetle obowiązującego porządku prawnego.

\section{Bibliografia:}

Lachowski J., Odpowiedzialność karna płatnika składek - wybrane zagadnienia, „Praca i Zabezpieczenie Społeczne” 2004, nr 12, s. 25-32.

Łabuda G., Komentarz do art. 218 Kodeksu karnego [w:] J. W. Giezek (red.), Kodeks karny. Część szczególna. Komentarz, LEX 2014.

Makowski K., Niektóre aspekty odpowiedzialności płatnika składek z tytułu popełnienia przestępstwa lub wykroczenia, „Przegląd Ubezpieczeń Społecznych” 2000, nr 5, s. 7-9.

Siwik Z., Komentarz do art. 218 Kodeksu karnego [w:] M. Filar (red.), Kodeks karny. Komentarz, LEX 2013.

Woźniewski K., Glosa do wyroku TK z 18 listopada 2010, P 29/09, „Gdańskie Studia Prawnicze - Przegląd Orzecznictwa” 2011, z. 2, s. 151-158. 